Reprod. Nutr. Dévelop., 1981, 21 (6A), 999-1007.

\title{
Comparison of ruminal and post-ruminal digestion of a concentrate feed in the young calf ( $\left.{ }^{1}\right)$
}

\author{
par A. BEN ASHER, Zafrira NITSAN *, I. NIR ** \\ Ministry of Agriculfure, Exfension Service, Tel Aviv, Israel \\ * Agricultural Research Organization, The Volcani Center, POB 6, Bet Dagan, Israel. \\ ** The Hebrew University of Jerusalem, Faculty of Agriculture, Rehovot, Israel.
}

Summary. Pre-ruminant calves were pair-fed a concentrate feed in either liquid form (LC) from a nipple bottle or in dry form (DC). We then studied the effects of these two forms of feed on body weight gain, feed utilization, digestibility, digestive enzyme secretion and volatile fatty acids in the rumen liquor.

The live weight gain of calves receiving the liquid concentrate was depressed by $34 p$. 100. The digestibility of total dry matter, protein, starch and energy was lower in the LC than in the DC group.

The daily amounts of trypsin, chymotrypsin and amylase excreted in the faeces were similar in both groups. Lipase secretion was significantly increased in the LC group. Due to a 2.7-fold increase in the amount of faeces excreted, faecal digestive enzyme concentration was depressed in the LC group.

Feeding dry concentrate to young calves reduced the $\mathrm{pH}$ in the rumen liquor and markedly increased the concentration of volatile fatty acids, especially $C_{2}, C_{3}$ and $C_{4}$.

The processes occurring in the rumen increased the digestibility of the concentrate protein by about 60 p. 100 and that of starch by 20 p. 100.

\section{Introduction.}

Young pre-ruminant calves fed milk or milk replacers ad libitum consume and digest enough nutrients to achieve a daily average growth of about $1 \mathrm{~kg}$ (Marshall and Smith, 1970). In practice, the growth of replacement heifers is reduced as restricted amounts of milk replacers are fed for economical reasons. The rather limited voluntary intake of dry concentrates does not allow a full expression of the growth potential in young calves. However, the urge to suckle at an early age permits the introduction of high amounts of feeds (including concentrates) when given in a liquid form. It was reported earlier that feeding liquid concentrate with a nipple bottle to young calves

(1) Contribution No. 104-E, 1980 series, from the Agricultural Research Organization, The Volcani Center, Bet Dagan, Israel. 
caused a quantitative passage of the food to the abomasum (Nitsan et al., 1978). Studies carried out with older calves (12-16 weeks of age) have shown that concentrate fed in a dry form was digested better than when fed in a liquid form (Raven and Robinson, 1961 ; Abe et al., 1978). However, the rumen is already considerably developed at that age.

The purpose of the present work was to compare the utilization of two forms (liquid and dry) of a concentrate feed given at a very early age (from 1 week) and to evaluate the contribution of the developing rumen.

\section{Material and methods.}

Animals, feeds and design. - Israeli-Friesian bull calves were purchased after they had received colostrum for 3 days, followed by a commercial milk replacer. At 5 to 7 days of age, the calves were allotted to two experimental groups of 5 calves each according to body weight and kept in individual pens with wooden-slatted floors. The milk replacer (table 1) (200 g/l) was pail-fed at $16.00 \mathrm{~h}$ once a day at $8 \mathrm{p} .100$ of body weight for the first 2 weeks, and then at 10 p. 100 of body weight for the next 3 weeks ; water was available at all times. One group received the dry form concentrate (DC) (table 1) and the other group the liquid form (LC). The concentrate $(200 \mathrm{~g} / \mathrm{l}$ of lukewarm water) was homogenized with an Ultra Turrax (T45 N, Janke and Kunkel KG, 7813, Stanfer, W. Germany) and was offered by nipple bottle at 07.00 and $16.00 \mathrm{~h}$. The

\section{TABLE 1}

Composition of experimental milk replacer and concentrate feed

\begin{tabular}{|c|c|c|}
\hline & Milk replacer $(\mathrm{g} / \mathrm{kg})$ & Concentrate $(\mathrm{g} / \mathrm{kg})$ \\
\hline 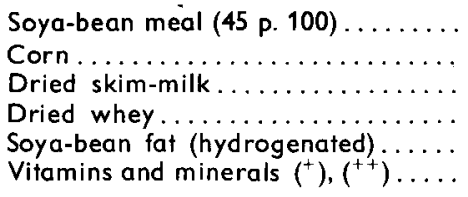 & $\begin{array}{r}- \\
700 \\
100 \\
180 \\
20\end{array}$ & $\begin{array}{r}320 \\
640 \\
- \\
\frac{20}{20}\end{array}$ \\
\hline \multicolumn{3}{|l|}{ Chemical composition $(\mathrm{g} / \mathrm{kg})$ : } \\
\hline $\begin{array}{l}\text { Dry matter } \ldots \ldots \ldots \ldots \ldots \ldots \ldots \\
\text { Crude protein }{ }^{*} \ldots \ldots \ldots \ldots \ldots \\
\text { Diethyl ether extract. } \\
\text { Starch } \ldots \ldots \ldots \ldots \ldots \ldots \ldots \ldots \\
\text { Ash } \ldots \ldots \ldots \ldots \ldots \ldots \ldots \\
\text { Gross energy }(\mathrm{MJ} / \mathrm{kg}) \ldots \ldots \ldots \ldots\end{array}$ & $\begin{array}{l}956 \\
263 \\
165 \\
- \\
78.3 \\
20.0\end{array}$ & $\begin{array}{c}889 \\
215 \\
53.6 \\
450 \\
38.5 \\
16.8\end{array}$ \\
\hline
\end{tabular}

$\left({ }^{+}\right)$To supply per $\mathrm{kg}$ of milk replacer : retinol, $8 \mathrm{mg}$; cholecalciferol, $0,2 \mathrm{mg}$; tocopheryl acetate, $560 \mathrm{mg}$; magnesium, $25 \mathrm{mg}$; manganese, $24 \mathrm{mg}$; iron, $16 \mathrm{mg}$; zinc, $20 \mathrm{mg}$; iodine, $7 \mathrm{mg}$; cobalt, $3 \mathrm{mg}$.

$\left({ }^{+}\right)$To supply per $\mathrm{kg}$ of concentrate : retinol, $2.7 \mathrm{mg}$; cholecalciferol, $0.05 \mathrm{mg}$; sodium bicarbonate, $4 \mathrm{~g}$; sodium chloride, $6 \mathrm{~g}$; dicalcium phosphate, $6 \mathrm{~g}$; methionine, $2 \mathrm{~g}$; manganese, $10 \mathrm{mg}$; cobalt, $2 \mathrm{mg}$; iron, $10 \mathrm{mg}$; copper, $0.5 \mathrm{mg}$; lodine, $1 \mathrm{mg}$; zinc, $30 \mathrm{mg}$; magnesium, $100 \mathrm{mg}$.

* $N \times 6.38$ for milk products; $N \times 6.25$ for corn and soya-bean meal. 
amounts fed daily were increased gradually between days 1 and 6 from 150 to $400 \mathrm{~g}$ and maintained at $400 \mathrm{~g} / \mathrm{d}$ up to day 14 , at $600 \mathrm{~g}$ between days 15 and 23 and at $800 \mathrm{~g}$ thereafter. The calves not voluntarily consuming the daily amount of the dry feed were force-fed with balls made by wetting the concentrate. When necessary, this forcedfeeding of the DC was carried out when the LC calves were fed. Average consumption was $18 \mathrm{~kg}$ of milk replacer and $20.5 \mathrm{~kg}$ of concentrate during the 35-day experimental period.

The calves were weighed at the start of the experiment and once a week thereafter. For 10 days, the faeces were collected in plastic bags which were changed twice daily and their contents frozen at $-20^{\circ} \mathrm{C}$. On the same days as the faeces, urine was collected in plastic bottles containing $200 \mathrm{ml}$ of $5 \mathrm{p}$. 100 sulfuric acid to prevent nitrogen loss.

The pooled faecal samples of each calf from each 2-day collection were homogenized with water $(1: 1, w / w)$ in a Waring blender.

Chemical analysis. - The dry matter of the feeds and the faecal homogenates was determined after drying at $105^{\circ} \mathrm{C}$; ash was determined after $2 \mathrm{~h}$ at $600^{\circ} \mathrm{C}$. The nitrogen in samples of feeds, faeces and urine was assessed with a Technicon Autoanalyzer (Industrial Meth. 18-69W) after digestion by the Kjedahl procedure. Non-protein nitrogen was determined by the same procedure after precipitation of the proteins in the faecal homogenates using 20 p. 100 trichloroacetic acid $(1: 1, v / v)$. Fat was determined according to Van de Camer (1949). Starch was measured as glucose by the glucose oxidase method (Hestrin-Lerner and Ben-Yonah, 1963) before and after hydrolization with $0.8 \mathrm{~N} \mathrm{HCl}$ and reflux on a boiling water bath for $6 \mathrm{hrs}$. Feed and freezedried faecal and urine samples were analyzed for gross energy using an adiabatic oxygen bomb calorimeter.

Enzyme activities. - Amylase (EC 3.2.1.1), lipase (EC 3.1.1.3), trypsin (EC 3.4.4.4) and chymotrypsin (EC 3.4.4.5) in the faeces were determined immediately after the homogenates were prepared, as described by Nitsan and Nir (1977). We used 12.7-mm Bausch and Lomb test tubes at $37^{\circ} \mathrm{C}$ when determining the units of enzyme activity. One unit was defined as an absorbance change of $10^{-2}$ absorbance units over a 3-min period for amylase and $10^{-3}$ absorbance units over a 120-min period for trypsin and chymotrypsin ; lipase units were defined as $\mu \mathrm{g}\left(\times 10^{-2}\right)$ of naphthol released at $37{ }^{\circ} \mathrm{C}$ over a 10 -min period.

Rumen liquor was obtained with a tube before the morning feeding on days 7, 14, 28 and 35 of the experiment. The fucsin-stained samples were examined microscopically and their $\mathrm{pH}$ determined immediately. The rumen liquor was frozen at $-20^{\circ} \mathrm{C}$ for subsequent determination of volatile fatty acids by liquid gas chromatography (Tagari, 1969).

The effect of dry or liquid feeding on the volume of liquor in the rumen was studied on three calves starting at one week of age. The calves were kept on one of the experimental regimes for one week and then shifted over to the other regime for the same length of time. The volume of the rumen liquor was measured using phenol red as an indicator (Hecker, Budtz-Olsen and Ostwald, 1964).

Statistical analysis. - The between-group differences were assessed by the t-test according to Snedecor and Cochran (1967). 


\section{Results.}

The growth rate of the LC calves was only $66 \mathrm{p} .100$ of that of the DC ones, in spite of equal feed consumption. Protein and energy utilization of the LC calves was about 65 p. 100 of that in the DC group and nitrogen was about 85 p. 100 (table 2).

TABLE 2

Body weight goin, feed consumption, and protein and energy utilization by calves fed dry or liquid concentrate (five calves/group, mean $\pm S E$ )

\begin{tabular}{|c|c|c|c|c|c|}
\hline \multirow[b]{2}{*}{$\begin{array}{l}\text { Experimental period }(\mathrm{d}) \ldots \ldots \ldots \\
\text { Initial body weight }(\mathrm{kg}) \ldots \ldots \ldots \\
\text { Body weight at weaning }(\mathrm{kg}) \ldots \ldots \\
\text { Body weight gain }(\mathrm{g} / \mathrm{d}) \ldots \ldots \ldots \\
\text { Feed consumption }(\mathrm{kg}):\end{array}$} & \multicolumn{2}{|c|}{ Dry } & \multicolumn{2}{|c|}{ Liquid } & \multirow{2}{*}{ 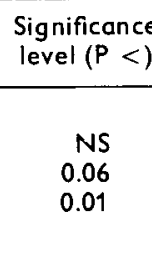 } \\
\hline & $\begin{array}{l}38.6 \\
62.9 \\
694\end{array}$ & $\begin{array}{l} \pm 2.9 \\
\pm 3.0 \\
\pm 20.7\end{array}$ & $\begin{array}{l}1-33 \\
39.8 \\
55.9 \\
460\end{array}$ & $\begin{array}{l} \pm 2.4 \\
\pm 2.4 \\
\pm 39.6\end{array}$ & \\
\hline $\begin{array}{l}\text { Milk replacer }{ }^{*}(\mathrm{~kg}) \ldots \ldots \ldots \\
\text { Concentrate }(\mathrm{kg}) \ldots \ldots \ldots \ldots \\
\text { Crude Protein }(\mathrm{kg}) \ldots \ldots \ldots\end{array}$ & $\begin{array}{l}18.2 \\
20.5 \\
9.18\end{array}$ & $\begin{array}{l} \pm 1.1 \\
\pm \quad 0.29\end{array}$ & $\begin{array}{c}18.0 \\
20.5 \\
9.12\end{array}$ & $\begin{array}{l} \pm 2.1 \\
\pm 0.25\end{array}$ & \\
\hline $\begin{array}{l}\text { Gross energy }{ }^{* *}(\mathrm{MJ}) \ldots \ldots \ldots \ldots \\
\text { Protein utilization (Weight gain } \\
\mathrm{kg} / \mathrm{kg} \text { protein intake)........ } \\
\text { Energy utilization (weight gain } \\
\mathrm{kg} / \mathrm{MJ} \mathrm{GE} \text { intake)............ }\end{array}$ & $\begin{array}{l}2.65 \\
0.034 \\
0.034\end{array}$ & $\begin{array}{ll} \pm & 0.08 \\
\pm & 0.001 \\
\pm & 0.001\end{array}$ & $\begin{array}{l}1.76 \\
0.023 \\
0.023\end{array}$ & $\begin{array}{ll} \pm & 0.04 \\
\pm & 0.002 \\
\pm & 0.002\end{array}$ & $\begin{array}{l}0.01 \\
0.05 \\
0.05\end{array}$ \\
\hline $\begin{array}{l}\text { Nitrogen retention }{ }^{* *}(p .100) \\
\text { Metabolisable energy }{ }^{* *}(p .100)\end{array}$ & $\begin{array}{l}51.7 \\
70.2\end{array}$ & $\begin{array}{l} \pm \quad 2.84 \\
\pm \quad 2.76\end{array}$ & $\begin{array}{l}44.1 \\
60.1\end{array}$ & $\begin{array}{l} \pm 3.10 \\
\pm \quad 1.18\end{array}$ & $\begin{array}{l}0.06 \\
0.05\end{array}$ \\
\hline
\end{tabular}

* 8 p. 100 of body weight during the first week and 10 p. 100 of body weight at the start of the second week and thereafter.

** Gross energy as determined.

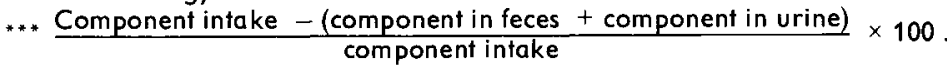

The LC calves excreted 2.7-fold more faeces than the DC calves (table 3). The concentration of faecal dry matter was similar in both groups. The composition of the dry faeces varied greatly between the two groups, the greatest differences being in the percentage of starch and glucose : 16.4 vs 3.4 and 6.4 vs 2.1 in the LC and DC groups, respectively. The higher starch concentration in the faeces of the LC group was probably responsible for its jelly-like appearance.

The apparent digestibilities of the feed constituents (fat excepted) and the energy of the whole diet (milk replacer and concentrate) were significantly lower in the LC than in the DC group. These differences were accentuated when the digestibility of the concentrate alone was calculated (table 3). The concentrations (units/g of dry matter) of amylase, trypsin and chymotrypsin in the faeces was higher in the DC than in the LCfed calves, while that of lipase was higher in the LC group. The total amounts of amylase, trypsin and chymotrypsin excreted in the faeces were similar for the two groups, but significantly higher levels of lipase were excreted by the LC than by the DC calves (table 4). 
TABLE 3

Faecal composition and apparent digestibility coefficients of the whole ration and of concentrote feed * (Means of 10 collection days)

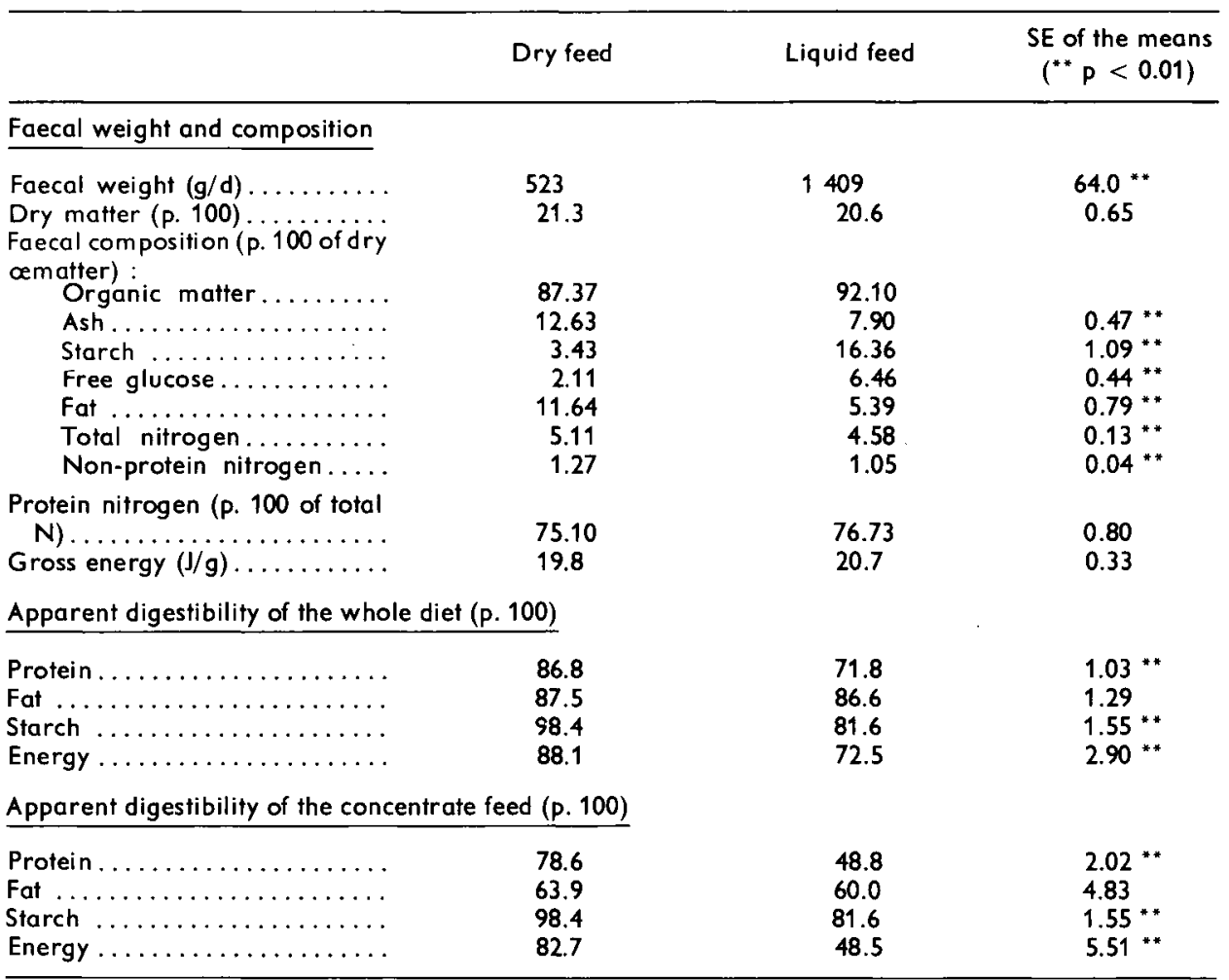

* Assuming that the digestibility of milk replacer components was : protein 95 p. 100, fat 96 p. 100 and ash 95 p. 100 (Nitsan et al., 1972). Starch was present in the concentrate only. Digestible energy 93 p. 100 according the NRC, 1978.

\section{TABLE 4}

Digestive enzymes excreted in the foeces of calves fed dry or liquid concentrate (means of 10 collection days)

\begin{tabular}{|c|c|c|c|c|c|c|}
\hline \multirow{2}{*}{ Enzyme } & \multicolumn{3}{|c|}{ Units/g dry matter } & \multicolumn{3}{|c|}{ Total units in the faeces/d } \\
\hline & Dry feed & Liquid feed & SEM & Dry feed & Liquid feed & SEM \\
\hline $\begin{array}{l}\text { Amylase } \ldots . . . \cdots \\
\text { Lipase ........... } \\
\text { Trypsin ......... } \\
\text { Chymotrypsin . . }\end{array}$ & $\begin{array}{l}0.70 \\
0.32 \\
1.74 \\
2.01\end{array}$ & $\begin{array}{l}0.36 \\
0.48 \\
0.89 \\
0.67\end{array}$ & $\begin{array}{l}0.1 \quad \mathrm{NS} \\
0.048^{* *} \\
0.22^{*} \\
0.34^{* *}\end{array}$ & $\begin{array}{l}77.5 \\
34.8 \\
186 \\
206\end{array}$ & $\begin{array}{l}93.5 \\
117.6 \\
225 \\
182\end{array}$ & $\begin{array}{l}3.41 \\
23.9^{*} \\
64.5 \\
103\end{array}$ \\
\hline
\end{tabular}

${ }^{*} p<0.05,{ }^{* *} p<0.01$. 
The $\mathrm{pH}$ of the rumen liquor (average of 4 samplings on days 7, 14, 28 and 35) was 6.85 and 6.04 for LC and DC-fed calves, respectively (the difference was statistically significant at $P<0.05$ ). In both groups, bacteria were detected in the rumen liquor at the first examination (day 7 of the experiment), but protozoa were not detected at any time during the experiment.

The levels of volatile fatty acids in the rumen liquor are shown in figure 1 . The concentration of each of the volatile fatty acids determined was greater in the DC than in the LC group. The levels of acetic, propionic and butyric acids increased in the DCfed calves during the experimental period, while no such changes were observed in the LC group.

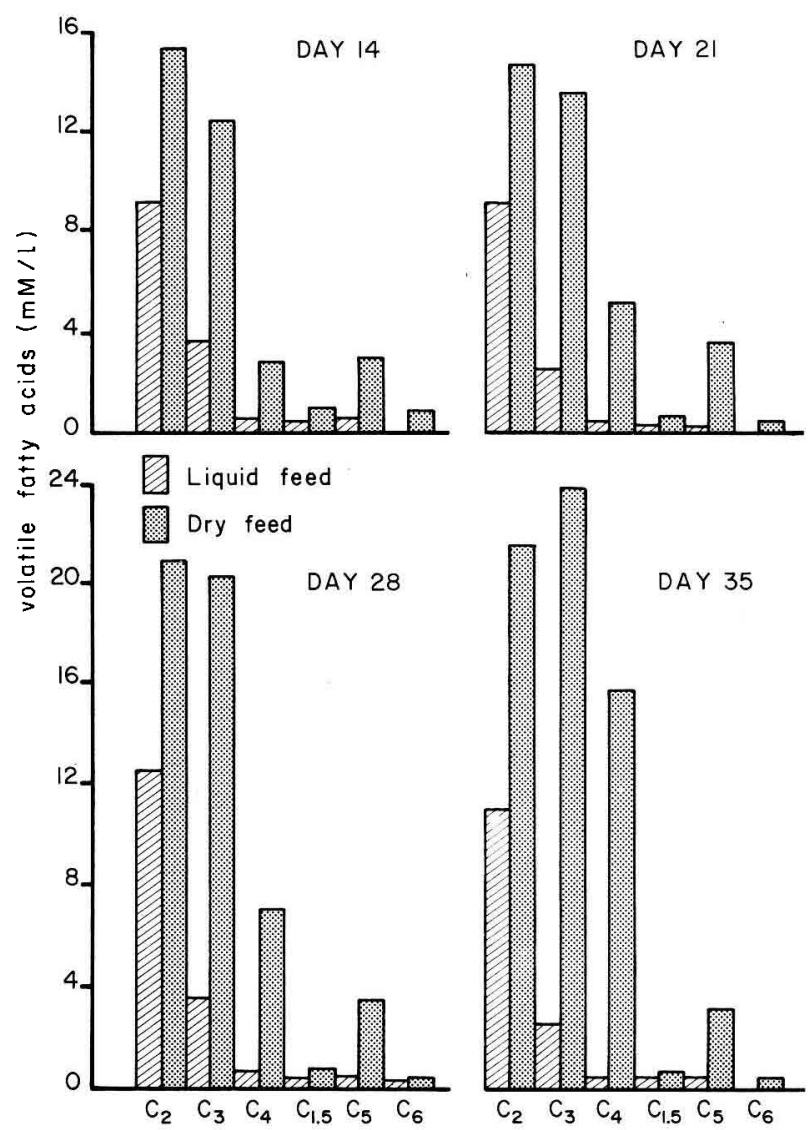

FIG. 1. - The levels of volatile fatty acids $(\mathrm{mM} / \mathrm{I})$ in the rumen liquor of calves fed liquid or dry concentrate.

The volume of the rumen liquor was always higher when the calves were fed the dry concentrate. The average volumes were 0.12 and $0.06 \mathrm{l} / \mathrm{kg}$ of body weight for the DC and LC-fed calves, respectively. 


\section{Discussion.}

When both groups of calves received the same amounts of milk replacer and concentrate offered in a liquid or solid form, the growth rate and protein and gross energy utilization of the LC-fed calves were reduced by about 34 p. 100 as compared with the DC-fed animals (table 2) ; this might be partly due to the higher digestive content of the LC-fed animals. According to Roy (1970), dry or liquid feed may affect the gut fill in young calves : the weight of the alimentary tract is much higher in the ruminant than in the pre-ruminant calf.

Assuming that the milk replacer was digested equally by the two groups of calves, the better digestibility of the concentrate fed in a dry form (table 3 ) is in accordance with the results of Abe et al. (1978) who worked with older calves $(12$ and 16 weeks of age). Fitzgerald and Kay (1974) did not find any differences. in the digestibility of concentrate feed given in either dry or liquid form by pail. Radiographic studies showed that the wet as well as the dry diet passed into the rumen which is the main site of digestion. Those authors stated that « the calves had continuous access to the wet feed during the feeding trial and consequently the conditioning effect associated with feeding of limited quantities of liquid feed in stimulating closure of the oesophageal groove was absent ». However, in the present study, the concentrate in a liquid form, fed with a nipple bottle, bypassed the rumen and was introduced directly into the abomasum as shown by radiography (Nitsan ef al., 1978). Concentrate fed dry is exposed to digestive processes in both the rumen and the small intestine; when fed in a liquid form, it undergoes intestinal digestion only. The digestive processes in the rumen of young calves are initiated by the presence of food. This assumption is confirmed by the marked increased in rumen liquor volume and volatile fatty acid content in the rumen and by changes in the ratios of acetic, propionic and butyric acids (fig. 1). In addition to the processes occurring in the rumen in situ, rumen contribution to improved digestibility might also be due to the fact that (i) partial digestion of the concentrate in the rumen improves its digestibility in the intestine, and (ii) the gradual release of concentrate from the rumen avoids loading the intestine and permits better exposure of the chyme to digestive and absorptive processes. It was shown earlier that the capacity of the abomasum and the small intestine of young calves to digest and absorb ingredients of plant origin is somewhat limited as compared to milk ingredients (Nitsan et al., 1972 ; Hinks and Armishaw, 1975 ; Sissons and Smith, 1976).

In the present study, the processes occurring in the rumen increased concentrate protein digestibility by about 60 p. 100 and that of starch by 20 p. 100 . It is known that protein degradation by microorganisms is higher in the rumen when the proteins are soluble. This may have a negative effect on the amino acid balance of dietary proteins in the calf ; Guilhermet (1977) assumed that utilization of the oesophageal groove could impair this negative effect. Unfortunately, we have no direct assessment of amino acid concentration or of concentrate protein solubility but it does not appear that bypassing the rumen can improve protein utilization of this type of diet. The absorption of ash increased by 139 p. 100 when the concentrate passed through the rumen, as compared with the liquid concentrate that bypassed the rumen. 
Digestive enzyme activity (units/g of dry matter) in the contents of the small intestine, as reflected by that activity in the faeces (Nitsan and Liener, 1976), was lower in the LC than in the DC-fed calves throughout the experimental period. Total digestive enzyme activity in the chick small intestine was shown to correspond to the amount of its intestinal contents (Nitsan et al., 1974 ; Nir and Nitsan, 1979). This is in accord with the suggestion that digestive enzyme production varies with fedeing status and may be regulated by the concentration of those enzymes in the intestinal contents (Green and Lyman, 1972). We did not observe this kind of regulation in the young calf. Markedly higher amounts of undigested feed reached the intestines of the LC-fed calves, but total enzyme excretion remained the same as in the DC-fed group. This resulted in lower concentrations of trypsin, chymotrypsin and amylase. The increase of lipase secretion in the LC group was compatible with unimpaired fat absorption.

\section{Conclusions.}

Food reaching the rumen initiates digestive processes in the calf independently of chronological age. At a very early age, the calf rumen is involved, considerably improving the digestibility and/or absorption of protein, starch and ash from concentrates of plant origin.

$$
\begin{aligned}
& \text { Reçu en janvier } 1981 . \\
& \text { Accepté en juin } 1981 .
\end{aligned}
$$

\section{Résumé.}

1. Nous avons étudié au cours d'une expérience de bilans l'effet de la distribution d'un aliment concentré sous forme liquide (LC) (administré à l'aide d'un seau à tétine), ou sèche (DC), sur la croissance, l'efficacité alimentaire, la digestibilité, la sécrétion d'enzymes digestifs et la concentration en acides gras volatils dans le jus de rumen chez le jeune veau.

2. Le traitement LC a entraîné une réduction de la croissance (34 p. 100) et de la digestibilité de la matière sèche, de l'azote, de l'amidon et de l'énergie.

3. Les excrétions fécales journalières de trypsine, de chymotrypsine et d'amylase ont été identiques dans les deux groupes. L'excrétion fécale de lipase a été supérieure dans le groupe LC. Du fait de l'augmentation de l'excrétion fécale $(\times 2,7)$, la concentration en enzymes digestifs dans les fèces a été inférieure avec le traitement LC.

4. Le traitement $\mathrm{DC}$ a été accompagné par une réduction du $\mathrm{pH}$ et par une augmentation remarquable du taux d'acides gras volatils $\left(C_{2}, C_{3}, C_{4}\right)$ dans le jus de rumen.

5. Le passage de l'aliment dans le rumen permet d'accroître la digestibilité apparente de l'azote et celle de l'amidon d'environ 60 et 20 p. 100, respectivement.

\section{References}

ABE M., SHIBUI H., IRIKI I., KONDOH K., KAWAI T., 1978. Effects of liquid feeding of concentrate from a pail on growth and on the digestibility of the diet in young calves. Br. J. Nutr., 39, 469482.

FITZGERALD J. J., KAY M., 1974. Studies on the intake and utilization of wet feed by calves. Anim. Prod., 19, 149-156. 
GREEN M. G., LYMAN R. L., 1972. Feedback regulation of pancreatic enzyme secretion as a mechanism for trypsin inhibitor-induced hypersecretion in rats. Proc. Soc. exp. Biol. Med., 140, 6-12.

GUILHERMET R., 1977. Alimentation du veau sevré précocement (Veau d'élevage), 184-206. In Le veau, P. MORNET, J. ESPINASSE. Maloine (Paris).

HECKER J. F., BUDTZ-OLSEN O. E., OSTWALD M., 1964. The rumen as a water store in sheep. Aust. J. agric. Res., 15, 961-968.

HESTRIN-LERNER S., BEN-YONAH S., 1963. Routine determination of blood glucose with glucose oxidase. Bull. Res. Counc. Israel, 10E, 188-191.

HINKS C. E., ARMISHAW A. M., 1975. The nutritive value of cooked potato in liquid and creep diets for early-weaned calves. Anim. Prod., 21, 31-40.

MARSHALL S. P., SMITH K. L., 1970. Effect of different milks and levels of intake upon growth of young dairy calves. J. Dairy Sci., 53, 1622-1626.

NIR I., NITSAN Z., 1979. Metabolic and anatomical adaptations of lightbodied chicks to intermittent feeding. Br. Boult. Sci., 20, 61-71.

NITSAN A., DROR Y., NIR I., SHAPIRA N., 1974. The effects of force-feeding on enzymes of the liver, kidney, pancreas and digestive tract of chicks. Br. J. Nutr., 32, 241-247.

NITSAN Z., BAR-GAI U., NIR I., BEN-ASHER A., 1978. The route and rate of feed passage through the gastrointestinal tract of young calves as determined by x-rays. Refuah Vet., 35, 21-22.

NITSAN Z., LIENER I. E., 1976. Enzymic activities in the pancreas, digestive tract and feces of rats fed raw or heated soy flour. J. Nutr., 106, 300-305.

NITSAN Z., NIR I., 1977. A comparative study of the nutritional and physiological significance of raw and heated soya beans in chicks and goslings. Br. J. Nutr., 37, 81-91.

NITSAN Z., VOLCANI R., HASDAI A., GORDIN S., 1972. Soybean protein as a possible substitute for milk protein in milk replacers for suckling calves. J. Dairy Sci., 55, 811-821.

NRC, 1978. Nutrient requirements of dairy cattle, 5th ed., Nat. Acad. Sci. Washington, D. C.

RAVEN A. M., ROBINSON K. L., 1961. Comparative effects of wet and dry feeding on the utilization of protein by calves. Nature, 30, 1256-1258.

ROY J. H. B., 1970. The calf. Iliffe Books Ltd., London, W.C. 1.

SISSONS J. W., SMITH R. H., 1976. The effects of different diets, including those containing soya-bean products, on digesta movement and water and nitrogen absorption in the small intestine of the preruminant calf. Br. J. Nutr., 36, 421-438.

SNEDECOR G. W., COCHRAN W. G., 1967. Statistical Methods, 6th ed., Ames, lowa, lowa State University.

TAGARI H., 1969. Comparison of the efficiency of proteins contained in lucerne hay and soya-bean meal for sheep. Br. J. Nutr., 23, 455-470.

VAN DE CAMER V., 1949. Rapid method for the determination of fat in feces. J. biol. Chem., 177, 347 352. 